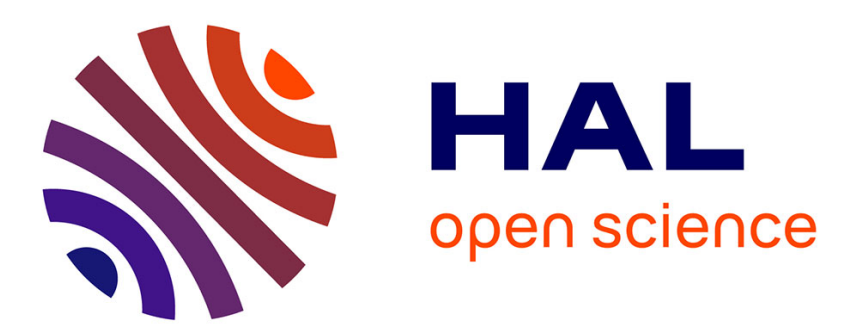

\title{
Clothing the Body, Dressing the Identity: the Case of the Japanese in Taiwan during the Colonial Period Ju-Ling Lee
}

\section{To cite this version:}

Ju-Ling Lee. Clothing the Body, Dressing the Identity: the Case of the Japanese in Taiwan during the Colonial Period. Journal of Japanese Studies, 2017, 43 (1), pp.31-64. 10.1353/jjs.2017.0003 . hal-02957034

\section{HAL Id: hal-02957034 \\ https://hal.science/hal-02957034}

Submitted on 7 Oct 2020

HAL is a multi-disciplinary open access archive for the deposit and dissemination of scientific research documents, whether they are published or not. The documents may come from teaching and research institutions in France or abroad, or from public or private research centers.
L'archive ouverte pluridisciplinaire HAL, est destinée au dépôt et à la diffusion de documents scientifiques de niveau recherche, publiés ou non, émanant des établissements d'enseignement et de recherche français ou étrangers, des laboratoires publics ou privés. 


\title{
Clothing the Body, Dressing the Identity: The Case of the Japanese in Taiwan during the Colonial Period
}

\begin{abstract}
In 1895, as soon as the Japanese arrived in Taiwan, their looser mores in terms of public nudity threatened to discredit Japan's "civilizing" mission in the colony. By domesticating the bare body of the colonizing Japanese through regulations, the Government-General sought to maintain its authority under the gaze of its colonized subjects. This article investigates the complexity of the Japanese identity in the colonial encounter by examining the process of the self-domestication of the body of the colonizer and revealing its connections to previous Japanese bodily experiences during the early Meiji period.
\end{abstract}

Policies of dress were enforced in the colonial legal framework of Taiwan and drew from Japanese experience earlier in the Meiji period. Through these policies, this study examines the construction of Japanese identity. In 1895, Taiwan was ceded to Japan under the terms of the Treaty of Shimonoseki that ended the Sino-Japanese War. Having just defeated China, its previous center of civilization, Japan felt itself superior to the Chinese as well as to the Taiwanese Han people and sought to carry the "civilizing" mission to its new colony. ${ }^{1}$ However, soon after their arrival on the

I'd like to express my deepest gratitude to the three anonymous referees for their profound and stimulating comments that helped enormously the improvement of this essay.

1. The Taiwanese Han people migrated from China from the seventeenth century. They settled mainly in the western plains of the island while the aborigines, the indigenous people of Taiwan living on the island long before the arrival of the Chinese, dwelled largely in the eastern mountains. "Taiwanese" is used here to refer to the Chinese immigrants. The Government-General applied two different systems of administration to areas inhabited by the Taiwanese and the aborigines. The latter came under its project of industrial promotion driven by the need to exploit the natural resources in the mountainous areas. The aborigines were excluded from the colonial legal system and denied basic human rights. See Fujii Shizue, 
island, the Japanese faced the destabilization of their authority because of differences in mores and bodily practices between the Japanese and Taiwanese. This essay examines the Japanese practices, especially among the lower classes, both men and women, of walking in the street with their bodies scantily covered and being naked to the public gaze when bathing. By contrast, the Taiwanese kept the traditional mores of Chinese culture which disdained public nudity and strictly forbade women to expose their bodies. The Japanese mores concerning public nudity, looser than those of the Taiwanese, blurred the distinction between the "civilized" colonizer and the "barbarian" Other. Colonial authorities took immediate measures to clothe the half-naked bodies of the Japanese people in Taiwan through legal prohibitions. The Japanese body was thereby "self-domesticated" through regulating clothing as well as bodily and cultural practices.

To be sure, Japanese self-domestication was not a unique experience for the colony of Taiwan. Since the beginning of the Meiji era, the government had regulated the bodily practices of its people as one of the measures of the "civilization and enlightenment" (bunmei kaika) movement. Historian Narita Ryūichi sees the formation of the modern urban sphere of Tokyo as the launching point of the civilization movement. He writes of civilizing the body by "taming" (junchi) it through regulating public behavior and personal hygiene in order to obtain a homogeneous urban sphere. ${ }^{2}$ By "domestication," I thus suggest a process of regulating the bare body, considered "savage" and opposed to the modern criteria of public decency by the Meiji leaders, in order to "tame" and civilize it. By adding "self" to this term, I stress that the domestication was first imposed by the Meiji government on its own people, the Japanese, in relation to the Western powers and later, by the colonial authorities, on the colonizing Japanese, in relation to the colonized Taiwanese. The self-domestication of the Japanese body in colonial Taiwan was a continuation of this practice in which the role of the body, undressed or dressed, and the nature of that dress, sustained the rhetoric of civilization and Japan's imperial expansion.

Key in this context is the assertion that colonialism was "as much involved in making the metropole, and the identities and ideologies of colonizer, as it was in (re)making peripheries and colonial subjects." ${ }^{3}$ This paradigm rejects the binary theories that consider colonialism a process

Riju shiqi Taiwan zongdufu de lifan zhengce (Taipei: Guoli Taiwan Shifan Daxue Lishi Yanjiusuo, 1989). Thus, the aborigines are not examined in this essay, as the regulations studied below were in effect only in areas inhabited by the Taiwanese.

2. Narita Ryūichi, "Teito Tōkyō," in Asao Naohiro, ed., Iwanami kōza Nihon tsūshi (Tokyo: Iwanami Shoten, 1994), Vol. 16, pp. 181-87.

3. Jean Comaroff and John L. Comaroff, Of Revelation and Revolution, Vol. 2: The Dialectics of Modernity on a South African Frontier (Chicago: University of Chicago Press, 1997), p. 22. 
of imposition from the metropole and investigates the ambiguities, complexities, and tensions in the colonial relationship. ${ }^{4}$ Faye Yuan Kleeman expresses clearly the ongoing process of the construction of identity in the colonial encounter: while the Other as colonial subject is an object to "conquer, contain, know, incorporate and, eventually, assimilate," the "I" is in a "constant identity crisis, forced repeatedly to redefine itself on a broader canvas that can incorporate the former Other while seeking a yet more exotic Other through which to define its boundaries." This study is interested in the experience of "I"of the Japanese identity when crossing borders. As we see in the previous contributions of Leo Ching, Oguma Eiji, Robert Eskildsen, and Paul Barclay, the imagery and the concept of the boundaries of being "Japanese" were shaped and defined between the rhetoric of civilization, race, and social class and consisted in a construction and representation of the Other and the "I" in relation to each other. ${ }^{6}$

The Meiji Restoration and Japan's imperial expansion from the late nineteenth century involved an essential process of reconstructing the Japanese ethnic and national identity. Since the beginning of the formation of

4. Mary Louise Pratt's major contribution, Imperial Eyes: Travel Writing and Transculturation (London: Routledge, 1992), is considered by many to denote a shift in colonial studies from analyzing how the colonized were changed to how the colonizer was transformed through the practice of colonialism. Pratt developed the concept of "contact zone," defined as a cross-cultural space in which "subjects are constituted in and by their relations to each other." It treats the relations among colonizers and colonized in terms of "copresence, interaction, interlocking understandings and practices, often within radically asymmetrical relations of power" (p. 7). Previous research on modernity and the formation of identity in the Japanese colonial empire has also viewed colonialism as a mutual and fluid process. See Tani E. Barlow, ed., Formations of Colonial Modernity in East Asia (Durham NC: Duke University Press, 1997); Faye Yuan Kleeman, "Modernity, History, and the Uncanny: Colonial Encounter and Epistemological Gap," in Rachael Hutchinson and Mark Williams, eds., Representing the Other in Modern Japanese Literature: A Critical Approach (London: Routledge, 2007), pp. 271-91.

5. Kleeman, "Modernity, History, and the Uncanny," p. 271.

6. Leo T. S. Ching, Becoming "Japanese": Colonial Taiwan and the Politics of Identity Formation (Berkeley: University of California Press, 2001); Oguma Eiji, "Nihonjin" no kyōkai: Okinawa, Ainu, Taiwan, Chōsen, shokuminchi shihai kara fukki undō made (Tokyo: Shin'yōsha, 1998); Robert Eskildsen, "Of Civilization and Savages: The Mimetic Imperialism of Japan's 1874 Expedition to Taiwan," American Historical Review, Vol. 107, No. 2 (2002), pp. 388-418; Paul D. Barclay, "Peddling Postcards and Selling Empire: Image-Making in Taiwan under Japanese Colonial Rule," Japanese Studies, Vol. 30, No. 1 (2010), pp. 81-110. See as well Robert Tierney, "Going Native: Imagining Savages in the Japanese Empire" (Ph.D. diss., Stanford University, 2005); David L. Howell, Geographies of Identity in NineteenthCentury Japan (Berkeley: University of California Press, 2005); Tessa Morris-Suzuki, ReInventing Japan: Time, Space, Nation (Armonk NY: M. E. Sharpe, 1998); Matthew Fraleigh, "Transplanting the Flower of Civilization: The 'Peony Girl' and Japan's 1874 Expedition to Taiwan," International Journal of Asian Studies, Vol. 9, No. 2 (2012), pp. 177-209. 
the modern nation of Japan, the Meiji elites, including the cabinet ministers who had been sent to the United States and Europe for two years, faced the dilemma of the middle position of Japan, halfway between civilization and savagery. Fukuzawa Yukichi, one of the most prominent Meiji scholars, following U.S. and European works classifying human societies into different strata from savage to civilized, had placed Japan in the middle ground of half-civilized (hankai) in order to encourage the Japanese people to move to the highest level, equivalent to Western civilization. ${ }^{7}$ By appropriating Western civilization and mimicking Western imperialism, the Meiji elites thought to weaken the nation's position in the middle ground and elevate its standing in the Western-dominated international order. The Japanese colonialism formed in this context carried a specific purpose: by constantly discovering and assimilating "savage" others within its empire, Japan attempted to obtain the relative role of the "civilized."

But here appeared the ambivalence of Japanese colonialism and its assimilatory policies. In an often-cited observation, the Japanese are racially close to the colonized Taiwanese and Koreans and all are influenced by Chinese culture. ${ }^{9}$ It is thus difficult to make a clear cultural and racial distinction between Japan and those it colonized. Before rendering the colonized people into the Other in order to assimilate them, the Japanese had first to construct their sense of self in relation to the colonized. I argue that in the preliminary stage of the colonial encounter, by defining and shaping the "civilized" characteristics of the colonizer through the domestication of the body, it became possible to make the colonized people the subject of acculturation to the Western-modeled and "civilized" Japanese culture that was still an ongoing process. Western civilization, upon which the modern Japanese concept of civilization lay, had itself been formed and reformed in the transformation of social and cultural conditions. The cultural phenomena of nudity, shame, and sexuality were tightly connected to the myth of civilization in Europe, and European colonization helped to shape the

7. Fukuzawa Yukichi, "Bunmeiron no gairyaku," in Fukuzawa Yukichi, Fukuzawa zen$s h \bar{u}$, Vol. 3 (Tokyo: Jiji Shinpōsha, 1898). For studies of the middle ground of Japan, see Eskildsen, "Of Civilization and Savages"; Komori Yōichi, Posutokoroniaru (Tokyo: Iwanami Shoten, 2001), pp. 14-25.

8. Robert Eskildsen argues that the exaggerated representation of the "savage" Taiwanese aborigines by commercial publications-newspapers, woodblock prints, and kawaraban (crude monochrome prints) — around the Taiwan Expedition of 1874 helped to justify Japan's colonization of Taiwan 20 years later. Eskildsen's criticism contextualizes the expedition within the Japanese appropriation of Western civilization and mimicry of Western imperialism in the early Meiji period. He thus dates the beginning of Japanese colonialism to earlier than the 1890s. Eskildsen, "Of Civilization and Savages."

9. Oguma Eiji, Tan'itsu minzoku shinwa no kigen: "Nihonjin" no jigazō no keifu (Tokyo: Shinyōsha, 1995), pp. 373-76. 
West's own bodily construction and its concept of modernity. ${ }^{10}$ In this study, I examine the role of the representation of the body, especially public nudity, in drawing the border between the realms of civilization and barbarism and in distinguishing the Japanese from people in the colony.

Japan's efforts to make itself equal with the Western colonial powers, while at the same time distinguishing itself from other Asian countries by colonizing them, represented Japanese colonialism caught in two views as seen by Komori Yōichi. According to Komori, the adoption of the Western concept of civilization was a form of self-colonization that he called "colonial consciousness" (shokuminchi shugiteki ishiki). This was a means by which Japan could avoid being colonized by the Western powers and considered a barbarian culture. Later, part of the suppressed memory of this transformed into "colonial unconsciousness" (shokuminchiteki muishiki), and Japan colonized its East Asian neighbors by adopting the Western colonial gaze. ${ }^{11}$ As Leo Ching points out, the Japanese gaze toward its colonial subjects "must always invariably redirect itself, somewhat ambivalently, to the imperialist glare of the West." This gaze oscillates uneasily "between being both the seeing subject and the object being seen," between the colonizer and the colonized. ${ }^{12}$ In this relationship, I argue, when Japan situated itself beneath the contemptuous gaze of Western powers, the Japanese body was domesticated to reduce its difference from the Western world, and when Japan entered into contact with its imperial subjects, the Japanese body was regulated to maintain its authority under the gaze of its colonized subjects.

To explore the self-domestication of the Japanese body, this study examines how policies of dress were enforced in the legal framework of Japanese colonialism. I analyze ikeizai ("police offenses"13) enforced in

10. See the fundamental contributions of Norbert Elias and Hans-Peter Duerr on the formation of the self-perception of Western European civilization: Norbert Elias, The Civilizing Process (New York: Urizen Books, 1978); Hans-Peter Duerr, Nacktheit und Scham (Frankfurt am Main: Suhrkamp, 1988); Hans Peter Duerr, Dreamtime: Concerning the Boundary between Wilderness and Civilization (Oxford: B. Blackwell, 1985).

11. Komori, Posutokoroniaru, pp. 14-25. The concept of the colonial "gaze" is introduced by Mary Louise Pratt through the narrative of "anti-conquest," by which she refers to the "strategies of representation whereby European bourgeois subjects seek to secure their innocence in the same moment as they assert European hegemony." Pratt calls the main protagonist of the "anti-conquest" the "seeing-men" whose "imperial eyes passively look out and possess." Pratt, Imperial Eyes, p. 7.

12. Leo Ching, "Yellow Skin, White Masks: Race, Class and Identification in Japanese Colonial Discourse," in Kuan-Hsing Chen, ed., Trajectories: Inter-Asia Cultural Studies (London: Routledge, 1998), p. 66.

13. For other works using the term "police offenses," see, for example, Wilhelm Röhl, ed., History of Law in Japan since 1868 (Leiden: Brill, 2005); Christopher Aldous, The Police in Occupation Japan: Control, Corruption and Resistance to Reform (London: 
Taiwan during the first decade of colonization, in comparison to the petty misdemeanor ordinances (ishiki kaii jörei; hereafter, Ordinances) enforced in early Meiji Japan. Both sets of regulations prohibited public nakedness. ${ }^{14}$ Most of the ikeizai articles applied to both Taiwanese and Japanese, but some were aimed specifically at Japanese and excluded the Taiwanese people. All of the articles that specifically addressed Japanese concerned public nudity. Previous studies have examined the early Meiji Ordinances through their influence on the modernization of Japanese society, conformed to the Western criteria of civilization perceived by the Meiji elites, and some have focused on the regulation of the body. ${ }^{15}$ However, research into the legal history of colonial Taiwan has developed only since the 1990s; studies of ikeizai there remain limited ${ }^{16}$ and only a few contributions address the regulation of the body. ${ }^{17}$ In her study on colonial legal control in Taiwan through colonial literary representations, Chu Huei-Chu examines enforcement of ikeizai by the Japanese police who were empowered to im-

Routledge, 1997); and Tay-Sheng Wang, Legal Reform in Taiwan under Japanese Colonial Rule, 1895-1945: The Reception of Western Law (Seattle: University of Washington Press, 2000).

14. Similar regulations were issued in the Japanese settlements in Korea in the late nineteenth and early twentieth century. As early as 1879 , three years after Fusan was opened as the first treaty port where Japan obtained the right of settlement and trading, petty misdemeanor ordinances regulated the clothing and bodily practices of the Japanese living there and included the prohibition of public nudity (Article 3). Other Japanese treaty ports opening later in Korea issued a succession of similar regulations. On the connection between the regulation of the body of the Japanese in early Meiji Japan and in Japanese settlements in Korea, see Yi Chong-min, "Keihanzai no torishimari hōrei ni miru minshū tōsei: Chōsen no baai o chūshin ni," in Asano Toyomi and Matsuda Toshihiko, eds., Shokuminchi teikoku Nihon no hōteki $k \bar{o} z \bar{o}$ (Tokyo: Shinzansha, 2004), pp. 319-52.

15. See Haruta Kunio, "Ishiki kaii jōrei no kenkyū: bunmei kaika to shomin seikatsu no sōkoku," Beppu Daigaku tanki daigakubu kiyo, No. 13 (1994), pp. 33-48; Imanishi Hajime, Kindai Nihon no sabetsu to sei bunka: bunmei kaika to minshū sekai (Tokyo: Yūzankaku, 1998); Matsunaga Shinobu, "Ishiki kaii jōrei to gaikokujin e no 'oteisai': ratai to irezumi no kinshi o megutte," Bunka shigen gakkai, No. 9 (2010), pp. 55-66; Momose Hibiki, Bunmei kaika: ushinawareta fūzoku (Tokyo: Yoshikawa Kōbunkan, 2008); Nakano Akira, Hadaka wa itsu kara hazukashiku natta ka: Nihonjin no shūchishin (Tokyo: Shinchōsha, 2010); Howell, Geographies of Identity, pp. 155-67.

16. See Wang Taisheng, Taiwan rizhishiqi de falu gaige (Taipei: Lian Jing, 1999); Koganemaru Takashi, "Rizhi Taiwan 'fazhi' de jiantao: cong bijiaoshi chufa" (Ph.D. diss., National Taiwan University, 2012), pp. 212-46; Xu Guozhang, "Taiwan rizhishiqi fanzui jijue zhidu chutan: zhidu de yanbian ji chengxiao tantao," in Guoshiguan Taiwan Wenxianguan, ed., Diqijie Taiwan zongdufu dangan xueshu yantaohui lunwenji (Nantou: Guoshiguan Taiwan Wenxianguan, 2013).

17. For example, the work of Dong Yiqiu on the Japanese construction of toilets in colonial Taiwan briefly mentions the prohibition of public urination in ikeizai and its enforcement in Taiwanese society. Dong Yiqiu, Diguo yu biansuo: rizhishiqi Taiwan biansuo xingjian ji wuwu chuli (Taipei: Taiwan Guji, 2005), pp. 26-29. 
pose physical punishment on the Taiwanese in cases of transgression. ${ }^{18} \mathrm{Chu}$ argues that, through the image of "parents punishing their children," the colonizers compared themselves with the "civilized guardian" who showed the "uncivilized and immature" colonized people the way to civilization. Her study explores exclusively literary works and does not evoke the bodily experience of the Japanese colonizer under these regulations.

More than a technology of domination by the colonial authorities, legal control was "fluid and relational, subject to negotiation, interpretation, and contestation at every level of its formulation and deployment," as suggested by Susan L. Burns. ${ }^{19}$ I am particularly interested in the formulation of the prohibitions in their cultural, political, and historical contexts, as well as their evolution and effect. I examine the Japanese bodily practices perceived to be opposed to modern criteria for public morals and decency since the early Meiji period, as well as who was controlled by the prohibitions. As I demonstrate, the changing role expected of the Japanese people in the country's transformation - from a newly formed modern nation to a unique Asian colonial power-is closely connected to the self-domestication of the Japanese body.

I first examine the bodily experience of the Japanese "citizen" (kokumin), a new concept, superseding the social distinctions of the Edo period. ${ }^{20}$ I then evoke the bodily experience of the Japanese "colonizer" in the context of the movement of the Japanese people from the metropole to the colony. Here, the Japanese "citizen" and "colonizer" represent a heterogeneous group divided by social status and geopolitical situation, whose

18. Chu Huei-Chu, "Zhimindi de guixun yu jiaohua—rizhishiqi Taiwan xiaoshuo zhong de jingmin guanxi," Taiwan wenxue yanjiu xuebao, Vol. 10 (2010), pp. 117-48.

19. Susan L. Burns, "Introduction," in Barbara J. Brooks and Susan L. Burns, eds., Gender and Law in the Japanese Imperium (Honolulu: University of Hawai'i Press, 2014), p. 7.

20. Western ideas of human rights and citizenship were central to the political philosophies adapted by Meiji intellectuals. During the late nineteenth century, kokumin, literally "the people of the country," was related to "national" or the Western notion of "citizen." It first appeared in the 1871 Household Register Law, after which it was widely used in place of the term "subject" (shinmin) in the Imperial Rescripts. According to Ikegami Eiko, the use of the term kokumin reveals that the Meiji leaders "struggled to codify and institute civic and political rights ... while simultaneously striving to create a modern sense of national identity" without the preceding development of a civic society (italics in original). Ikegami Eiko, "Citizenship and National Identity in Early Meiji Japan, 1868-1889," International Review of Social History, Vol. 40 (1995), pp. 189-90. On the other hand, the term shimin (literally "the people of the city"), created in the mid-nineteenth century, is also the translation for "citizen." However, it was not used in Japanese legal texts in the Meiji period and was generally used to denote urban dwellers rather than to refer to active political citizenship. In prewar Marxist discourse, the term shimin began to be associated with the idea of universal human rights and freedom when some Marxists started to substitute shimin for the term burujowa (bourgeois), which had a negative connotation. See Simon Andrew Avenell, Making Japanese Citizens (Berkeley: University of California Press, 2010), pp. 72-73. 
mores in terms of public nudity were very diverse. In fact, after the abolition of the rigid social hierarchy in the early Meiji period, differences in mores and bodily practices between the upper and lower classes did not disappear immediately. ${ }^{21}$ As Umetani Noboru points out, a distinctive feature of Meiji modernization was that the mores of the ruling class and the bourgeoisie, which embraced the Western criteria of civilization, were then imposed on the general public; moreover, the rapid promotion of modernization resulted in a "superficial Westernization" of large cities while rural areas were much less affected. ${ }^{22}$ This was the main reason why, nearly 30 years after the beginning of the modernization of Japanese society, the self-domestication of the Japanese body still seemed necessary when numbers of lower-class Japanese from the rural areas of the metropole arrived in the colony of Taiwan. Imanashi Hajime also proposes that the prohibition of nudity created a "national body" (kokuminteki karada) and that this creation produced a concrete "sphere" for commoners (minshū sekai no gutaiteki "ba"). This shows the close relationship between the domestication of the body and the construction of the new social order as well as of modern urban space in the Meiji era. ${ }^{23}$

In Europe, the rising bourgeoisie considered the underclass of the metropole to be a great threat to civilization. John L. Comaroff and Jean Comaroff argue that the elevation of the colonized in the colony served both as a justification of the civilizing mission and as an example for reconstruction in the metropole. The colonies thus became "models of and for the 'improvement' of the underclasses" in the metropole. ${ }^{24}$ Based on the Comaroffs' elaboration, Chu Huei-Chu's study of the autobiographies of Japanese immigrants to Taiwan from Yaeyama Island in Okinawa, between the 1920s and 1944, demonstrates the intermediary role of the colony in transplanting modernity between the metropole and its periphery. ${ }^{25} \mathrm{Chu}$

21. From 1869, the Meiji government abolished the hierarchy of samurai, farmers, artisans, and merchants applied by the Tokugawa shogunate. The former samurai class became the gentry class (shizoku) and the other classes the commoner class (heimin). In 1871, the pariah class (senmin), which had been placed outside the Edo-period hierarchy, was incorporated into the commoner class.

22. Umetani Noboru, Nihon kindaika no shosō (Kyoto: Shibunkaku, 1984), p. 103.

23. See Imanishi Hajime's contribution on the relation between the civilization and enlightenment movement and commoners (minshü): Kindai Nihon no sabetsu to sei bunka, pp. $129-80$.

24. Comaroff and Comaroff, Of Revelation and Revolution, p. 24.

25. Chu Huei-Chu, "Zuowei jiaojiechangyu de 'xiandaixing': wangfan yu Chongsheng Bachongshan qundao yu zhimindi Taiwan zhijian," Wenhua yanjiu, Vol. 5 (2007), pp. 49-86. Chu's study focuses on the period from the 1920s for two reasons. First, the economic depression in the Okinawa islands during the 1920s resulted in significant emigration to the colony of Taiwan; second, the colonial modernization of Taiwanese cities was achieved during the same period, meaning that later Okinawan emigrants experienced a sharper difference in 
shows that the Okinawan people, affected somewhat later by the process of modernization than Japanese in urban areas, first experienced modernization in the colony and then imported it back to the homeland. However, for reasons of time period and focus, Chu's study could not offer a broader perspective on the general movement of the Japanese population to Taiwan from the late 1890s, nor could it show that the process of modernizing and civilizing the colonizer in the colony had taken place from the very beginning of colonization. ${ }^{26}$ Based on the premise that the colony of Taiwan was where the precarious and contested modernization of Japanese society was reexamined and improved, this study demonstrates the reconstruction and civilization of the lowly from the metropole through the domestication of the body in the colonial legal framework. Colonialism, as pointed out by Robert Delavignette, "has never been a one-way affair."27

\section{Clothing the Japanese Citizen}

"Civilization and enlightenment," a Western-inspired version of civilization adopted by Meiji elites, called for significant transformations in Japanese daily life. In the early Meiji period, the strict social hierarchy of the Edo period was abolished and replaced by the concept of "citizen." All Japanese citizens were encouraged to participate in the formation of the new modern nation, through the political process and economic activities as well as daily practices. ${ }^{28}$ With imported Western models of central institutions, the Meiji government had direct control over the lives of indi-

the modernization of Taiwan and their homeland than was the case for those who arrived in Taiwan during the first years of colonization.

26. The self-identification of Okinawan people as being Japanese was itself a late nineteenth- and early twentieth-century construction. The identity of Okinawan people had always oscillated between the Chinese and the Japanese, as a historical result of the islands' long-established tributary relationship with China and Japan. In 1879, the Meiji government annexed Okinawa, making it Okinawa Prefecture, and began implementing "civilizing" and Japanizing measures. See Oguma, "Nihonjin" no kyōkai, pp. 35-49, 280-319. As Chu's study shows, the identity of the Okinawan people in colonial Taiwan seems to have been complex: on the one hand, they considered themselves superior to the colonized Taiwanese, but, on the other hand, they were disdained by Japanese from the metropole and suffered the same discriminatory treatment in the colony as the colonized Taiwanese. See Chu, "Zuowei jiaojiechangyu de "xiandaixing",; and Matsuda Hiroko, "Yaeyama: From Periphery of the Ryūkyūs to Frontier of Japan," Japanese Studies, Vol. 28, No. 2 (2008), pp. 149-64.

27. Robert Louis Delavignette, Christianity and Colonialism (New York: Hawthorn Books, 1964), p. 9.

28. During the Edo period, the nonsamurai population was excluded from the political process and could not assume government positions. The rigidity of the system of status distinction worked both ways; the samurai were not to engage in commercial activities. Ikegami, "Citizenship and National Identity," pp. 192-94. 
viduals. ${ }^{29}$ Daily life was scrutinized in a series of regulations concerning public decorum that conformed to the Western criteria of civilization; at the same time, the Japanese body was domesticated to construct the "civilized" Japanese citizen. With increasing contacts between Westerners and Japanese after the opening of the major port cities, cultural differences noted by Westerners, such as mixed-gender public baths, public nudity, and the phallus cult, were interpreted as signs of decadence and a lack of morals in Japanese culture. ${ }^{30}$ One Japanese newspaper stated that the daily sight of "indecent nudity, with only a few items of clothing wrapped around the body," was the first thing that surprised newly arrived foreigners. ${ }^{31}$ The Japanese elites, concerned about elevating Japan's status in the Westerndominated international world, were highly aware of Westerners' criticisms of Japanese customs. As a consequence, the Japanese authorities issued several regulations to prohibit public nudity, aimed mainly at members of the lower classes. In 1868, Yokohama prohibited nudity among physical laborers such as rickshaw pullers and construction workers. ${ }^{32}$ In November 1871 , Tokyo Prefecture (Tōkyō-fu) issued a prohibition of public nudity targeting those such as physical laborers and "people who go undressed in and out of the public bath." It specified that in the "frequent contact with foreigners," public nudity was a "huge shame" and risked causing "the disdain of foreign countries." ${ }^{33}$

During the Edo period, the bakufu had restricted the costume and the lifestyle of the lower classes to maintain their difference from the upper class, making the dressed or undressed body a marker of status distinction. ${ }^{34}$ Lower-class Japanese were, by default, less clothed than the ruling class because of the need to do physical work (see Figure 1). Workmen stripped down to their loincloths and women loosened their clothing during warm weather. ${ }^{35}$ Showing the bare body was also a way for lower-class men

29. The Tokugawa shogunate did not develop a central institution of social control that directly governed individuals. Instead, mid-range social organizations served the ends of the state. Ibid.

30. See examples given in Momose, Bunmei kaika, pp. 40-55; see also Nakano, Hadaka wa itsu kara hazukashiku natta ka, pp. 21-26.

31. Yokohama shinpō moshihogusa, September 23, 1868.

32. Kanagawa-ken Kenshi Henshūshitsu, Kanagawa kenshi, shiryō hen (Yokohama-shi: Kanagawa-ken, 1970), p. 816.

33. Tōkyō-to, Tōkyōshi shikō: Shigaihe-52 (Kyōto: Rinsen Shoten, 2001), p. 575.

34. By controlling daily practices and the lifestyle of the lower classes, the bakufu also intended to minimize the influence of economic progress on their lives, afraid that it would make them engage less in labor and more accustomed to a comfortable lifestyle. See Kanazawa Yasutaka, Edo fukushokushi (Tokyo: Seiabō, 1962), pp. 24-27. These restrictions were abolished with the collapse of the system of social hierarchy.

35. Charles James Dunn, Everyday Life in Traditional Japan (London: Batsford, 1969), pp. 59, 143. See also examples of daily scenes of public nudity witnessed by Western travelers 


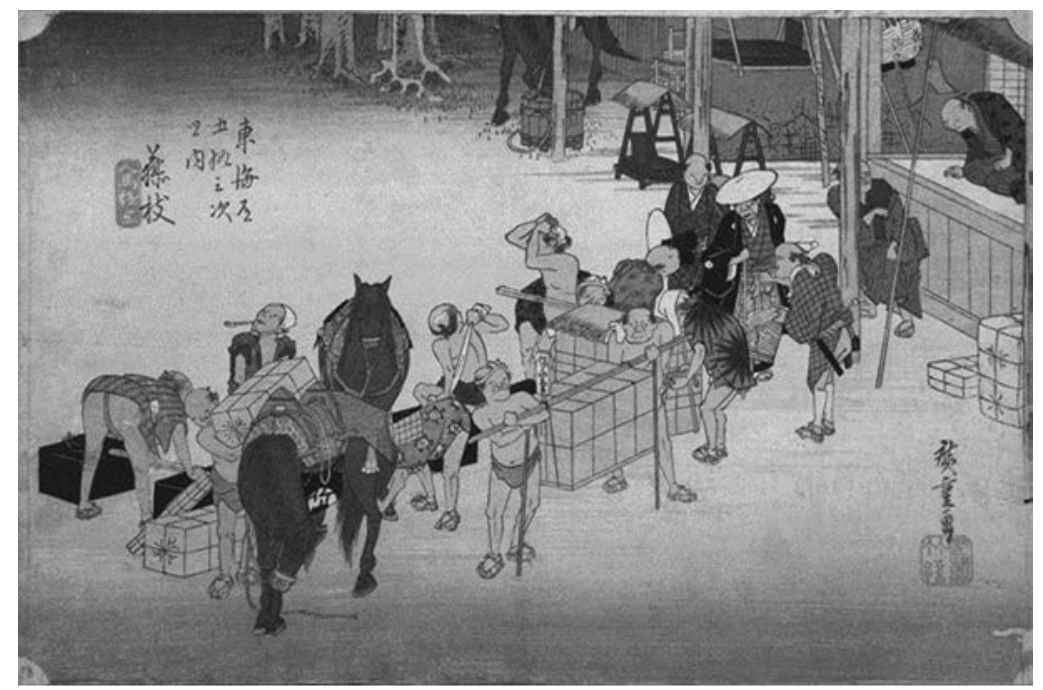

Figure 1. In this ukiyo-e painting by Utagawa Hiroshige, quasi-naked transporters contrast with the well-dressed samurai standing at the end of the line. (C) Tokyo Fuji Art Museum Image Archives/DNPartcom (reproduced by kind permission of Tokyo Fuji Art Museum).

to display masculinity: "During summertime in Edo city, lots of seminaked craftsmen walked on the street wearing only a fundoshi [loincloth] with a straw-string of Tenpo tsūhō [nineteenth-century coins] tied on the side. They became even more conceited when other men on the street praised them, saying they looked dashing." 36

As early as the arrival of the U.S. delegation led by Matthew Calbraith Perry in 1853, a lack of morals among the lower classes was noted in their practice of mixed-gender bathing in public:

The scene at one of the public baths, where the sexes mingled indiscriminately, unconscious of their nudity, was not calculated to impress the Americans with a very favorable opinion of the morals of the inhabitants. This may not be a universal practice throughout Japan, and indeed is said by the Japanese near us not to be; but the Japanese people of the inferior ranks are undoubtedly, notwithstanding their moral superiority to most oriental nations, a lewd people. ${ }^{37}$

in Japan in the early Meiji period given in Nakano, Hadaka wa itsu kara hazukashiku natta $k a$, pp. 85-100.

36. Kawasaki Fusagorō, Meiji Tōkyō shiwa: shijitsu ni miru yonjūgonen no hensen (Tokyo: Tōgensha, 1968), p. 38.

37. Matthew Calbraith Perry, Lambert Lilly, and George Jones, Narrative of the Expedition of an American Squadron to the China Seas and Japan: Performed in the Years 1852, 


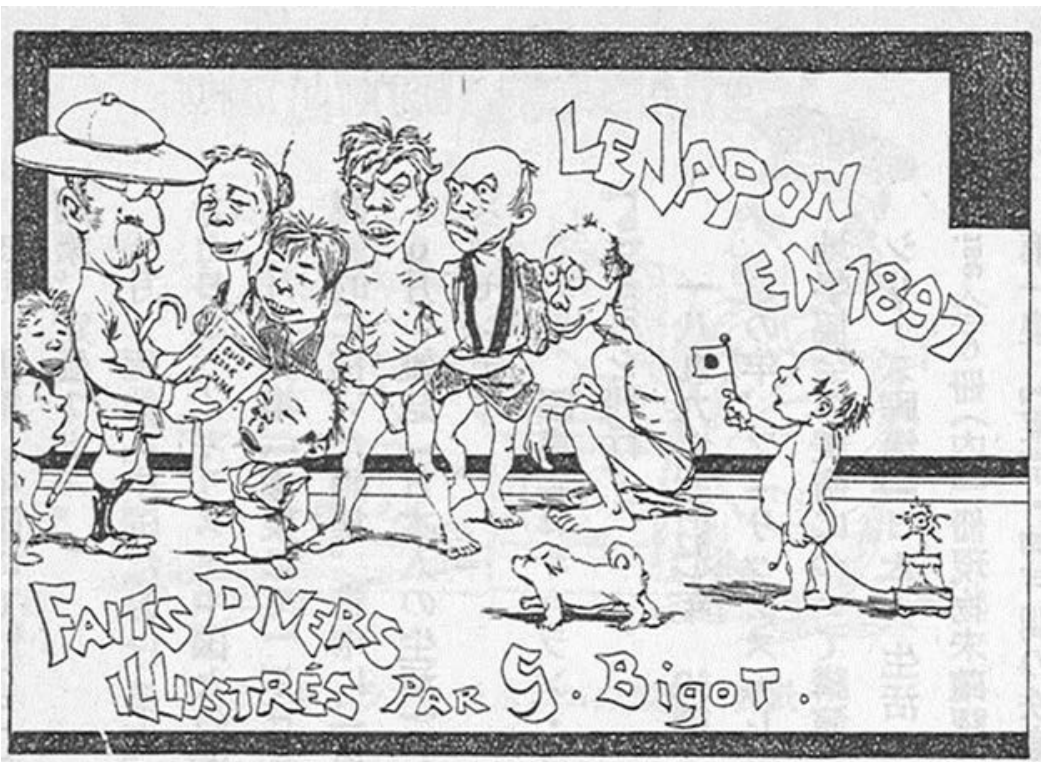

Figure 2. "Le Japon en 1897" (Japan in 1897). Illustration from Shimizu Isao, ed., Bigō Nihon sobyōsh $\bar{u}$ (Tokyo: Iwanami Shoten, 1986), p. 205 (reproduced by kind permission of Bijutsu Dōjinsha).

In 1868, a few months after the establishment of the Meiji regime, the new government issued a prohibition of mixed-gender public baths in the foreign settlement in the Tsukiji area of Tokyo. In his studies on nudity in Japan during the nineteenth century, Nakano Akira showed that bathing practices varied with social status and region. While the practice of mixed-gender bathing prevailed all over Japan from the Edo period among the lower classes, the upper class strictly respected the absolute distance between men and women and went to public baths that were separated by sex. ${ }^{38}$ Nevertheless, the Westerners who came to Japan in the early Meiji period identified the nudity of the lower classes as proof of the half-civilized status of Japan. The French caricaturist Georges Ferdinand Bigot, for example, frequently drew naked Japanese to represent "backward" Japan facing the "civilized" Western world (see Figure 2). ${ }^{39}$ "Modern Japan" in the

1853, and 1854, under the Command of Commodore M. C. Perry, United States Navy, by Order of the Government of the United States (Washington: Beverley Tucker, 1856), p. 405.

38. Nakano, Hadaka wa itsu kara hazukashiku natta ka, pp. 80-84.

39. Georges Ferdinand Bigot arrived in Japan in 1882 and worked as an art teacher, created illustrations for Japanese newspapers, and later published a satirical newspaper, Tôbaé. He left a rich collection of illustrations representing the daily life he witnessed during his 17 years in Japan. 


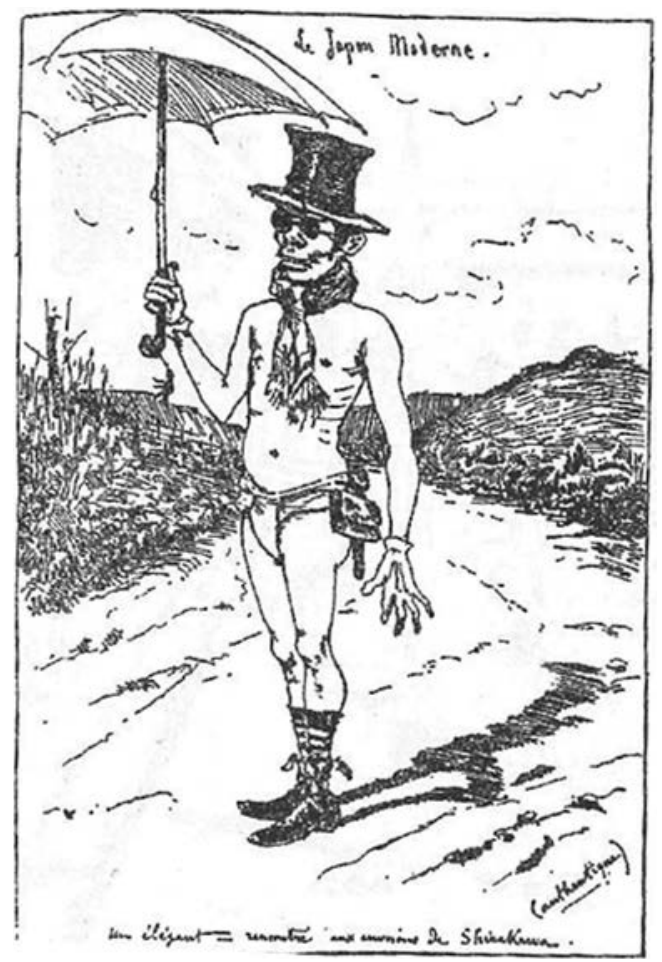

Figure 3. "Le Japon Moderne" (The Modern Japan). Illustration from Shimizu Isao, ed., Bigo no 150-nen: ishoku Furansujin gaka to Nihon (Kyoto: Rinsen Shoten, 2011), p. 331 (reproduced by kind permission of Bijutsu Dōjinsha).

eyes of Bigot was, nevertheless, the representation of a half-naked Japanese wearing a traditional loincloth with Western accessories (see Figure 3). The surprised gaze of Westerners on the barely dressed Japanese commoners reminded the Meiji elites that all citizens should now take part in the construction of a "modern" and "civilized" Japan. The awareness of "inappropriate" nudity in the early Meiji period was thus closely intertwined with changes in the role of lower-class Japanese during the formation of the modern nation. However, the actual effect of prohibitions published in the first years of the Meiji period remained very weak because of the lack of manpower to enforce them and the incomplete modern police system. ${ }^{40}$

In December 1872 Tokyo Prefecture published, for the first time in Japan, petty misdemeanor ordinances. The Ordinances were a body of articles

40. See Tōkyō-to, ed., Bannin seido: Meiji shonen no jichitai keisatsu (Tokyo: Tōkyō-to, 1973); Tokunaga Takashi, "Meiji shonen no toshi minshū shihai: Tōkyō ishiki kaii jōrei seitei zengo," Rekishi hyōron, No. 405 (1984), pp. 21-39. 


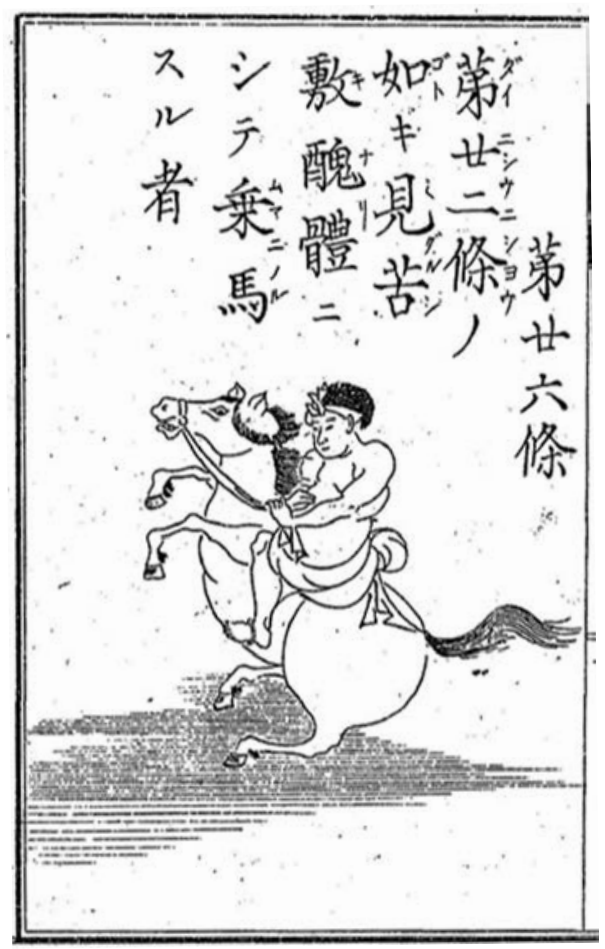

Figure 4. Tōshichi Hosoki, ed., Ishiki kaii jōrei (Tokyo: Yōyōdō, 1878), Fold 14. National Diet Library Digital Collections (reproduced by kind permission of the National Diet Library). This illustration represents a man riding a horse wearing only a loincloth. It refers to Article 26 of the Tokyo Prefecture Ordinances, which prohibited "riding a horse in a scandalous manner as prescribed in Article 22."

comprised of major contraventions (ishiki) and minor contraventions (kaii) such as acts of negligence or accidents that disturbed the public. ${ }^{41}$ In concert with the enactment of these Ordinances, a system of watchmen (bannin) was created in October 1872. Later replaced by the modern patrolling constable (junsa), established by the Tokyo Metropolitan Police Department in 1874 , this system greatly strengthened police control in Tokyo. ${ }^{42}$ Moreover, enforcement of the Ordinances was left entirely to police officers who were empowered to administer punishments under their own authority. ${ }^{43}$ Of the

41. Röhl, ed., History of Law in Japan, p. 142. Most of the articles that directly concerned public nudity were included in the ishiki. From 1882, the Ordinances were renamed ikeizai under the Penal Code of July 1880.

42. Tōkyō-to, Bannin seido; Röhl, History of Law in Japan, pp. 134-38.

43. See Tokunaga, "Meiji shonen no toshi minshū shihai." The ishiki offenses were punishable by fines from 75 to 150 sen, or from 10 to 20 lashes for those who could not afford 


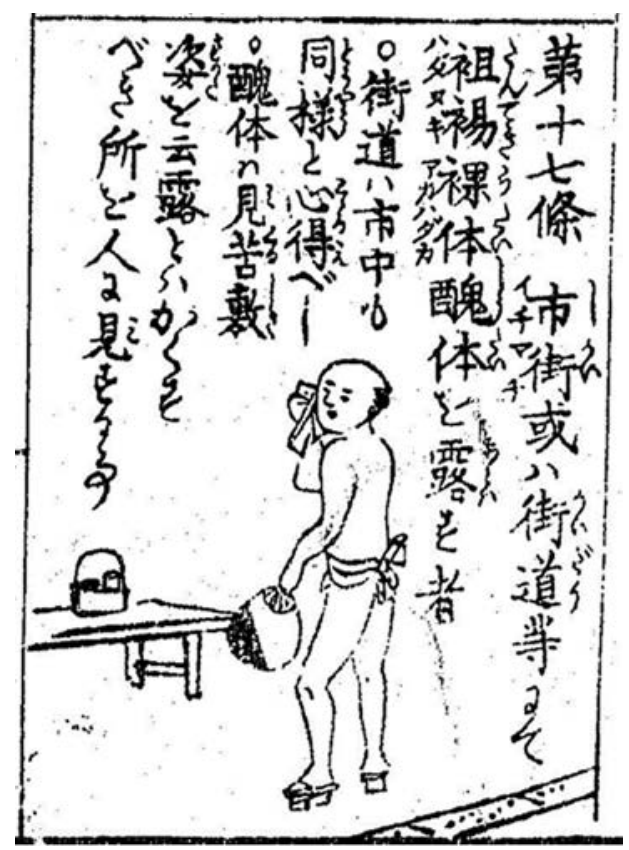

Figure 5. Shinshō Kimura, ed., Ishiki kaii zukai (Kyoto: Kōhōdō, 1877), Fold 4. National Diet Library Digital Collections (reproduced by kind permission of the National Diet Library). This illustration of a man on the street wearing only a loincloth refers to Article 17 of the Kyoto Prefecture Ordinances, which prohibited public nudity.

53 articles in the Ordinances, three directly concerned public nudity: the prohibition of going naked or topless or showing thighs or legs on the street (Article 22), or when riding a horse (Article 26) (see Figure 4), and the prohibition of mixed-gender bathing (Article 12). ${ }^{44}$ These were similar to prohibitions previously issued separately by Tokyo Prefecture. Later, other prefectures were authorized to establish their own Ordinances, depending on local circumstances (see Figure 5).

Compared to metropolitan areas, in rural areas where economic life depended largely on physical labor, which required convenient working

the fines. The kaii offenses were punishable by fines from 6 sen and $25 \mathrm{mo}$ to $12 \mathrm{sen}$ and $5 \mathrm{rin}$, or from one to two days of detention for those who could not pay.

44. Naikaku Kirokukyoku, ed., Hōki bunrui taizen, Vol. 27 (Tokyo: Naikaku Kirokukyoku, 1891), pp. 4-6. In 1871, the prohibition on the daily practice of horse riding by the lower classes was lifted. Former members of the lower classes who were accustomed to dressing scantily now rode horses dressed the same way. This became of concern to the Japanese elites, and several prohibitions had already been issued prior to the publication of the Ordinances. Ishii Kendō and Kida Junichirō, Zōtei Meiji jibutsu kigen (Tokyo: Kuresu Shuppan, 2004), pp. 644-45. 
clothes, resistance against the Ordinances seemed stronger. During 1873-74 several districts in Kyoto Prefecture (Kyōto-fu) demanded an "allowance for nudity" (ratai yūmen) because the majority of local inhabitants were engaged in agriculture. Prefectural authorities acquiesced ${ }^{45}$ In March 1874, in response to increasing complaints that the Ordinances were not adapted to the conditions of local life, the Meiji government issued an edict to encourage its prefectures to progressively implement the Ordinances. Prefectures were permitted to forgo the penalty officially stated by the Ordinances and instead only strictly admonish (setsuyu) offenders. However, the edict specified that this leniency would not occur in the "Three Capitals and Five Ports" where Westerners had the right to reside-Tokyo, Kyoto, and Osaka; and Hakodate, Kobe, Nagasaki, Niigata, and Yokohama, respectively. This shows that the self-domestication of the Japanese body was reinforced under the Western gaze and suggests an inconsistency between the metropolitan cities and the periphery in the process of civilization and modernization promoted by the Meiji government. ${ }^{46}$

The British traveler Isabella L. Bird witnessed this uneven process of modernization that led to different attitudes toward nudity in the cities and the peripheries. During her trip to Japan in 1878, Bird and her Japanese interpreter saw daily scenes of nudity in a small town called Fujihara: "The men may be said to wear nothing. Few of the women wear anything but a short petticoat wound tightly round them. . . The short petticoat is truly barbarous-looking . . . I can hardly believe myself in 'civilized' Japan." ${ }^{, 77}$ The day after their arrival in the town, her interpreter, who was "ashamed for a foreigner to see such a place," entreated her to leave, emphasizing that he "would not have believed that there was such a place in Japan" and "people in Yokohama will not believe it when he tells them of it and of the costume of the women. ${ }^{, 48}$ For the Japanese interpreter, the nudity in the daily life in Fujihara created an image of the periphery as a world situated in a time other than the "modern" one of the metropolitan port city of Yokohama. His reaction showed the extent to which an awareness of nudity on the part of the Japanese elites was constructed within the scrutiny of the Western gaze and the Western criteria of civilization. The making of the "national" and "modern" body through policies of dress during the Meiji period was thus imposed from the top down, from the cities to the periphery.

45. See Momose, Bunmei kaika, pp. 109-12; Imanishi, Kindai Nihon no sabetsu to sei bunka, pp. 163-66.

46. Momose, Bunmei kaika, p. 95; Imanishi, Kindai Nihon no sabetsu to sei bunka, p. 46.

47. Isabella L. Bird, Unbeaten Tracks in Japan: An Account of Travels in the Interior, including Visits to the Aborigines of Yezo and the Shrine of Nikkô, $2 \mathrm{~d}$ ed. (London: J. Murray, 1907), p. 83.

48. Ibid., p. 86 . 
The Japan-British Exhibition of 1910 further demonstrates the link between nudity, the lower classes, and the Western gaze when Japanese crossed borders. In the nineteenth century, participating in or holding an exhibition was an opportunity for a country to show off its achievements and power. In 1851, Britain held the Great Exhibition in which its colonies participated; it was considered the first truly international exposition in terms of the number of participating countries. The 1910 exhibition held by Japan and Britain, the most powerful imperialist nation at the time, symbolized the equal partnership of the two countries and had strong significance for Japan. It announced in some way that Japan was ready to bring civilization to people in Asia, following in the footsteps of its partner Britain. ${ }^{49}$ The Japan-British Exhibition featured several examples of buildings to showcase everyday life in Japan, populated by Japanese chosen to participate in the exposition. Among them were craftsmen, peasants, sumo wrestlers, and traditional art entertainers, all belonging to the former lower classes. Their way of dressing was reported by a Japanese correspondent as "scandalous":

At the beginning, the Japanese and craftsmen in the Japanese city and the Uji village walked in the center of London wearing only straw sandals without any overgarment or socks - there is no need to mention [how they were dressed] when they were in the exhibition hall. The Commission warned them about their ridiculous look. They have begun to get themselves used to going out with socks, but other scandalous behavior ... has drawn the attention of police. ${ }^{50}$

At the same time as the prohibition of public nudity, the matter of feet also became an issue of concern for the Meiji elites. The habit among the lower classes of walking barefoot and the use of traditional footwear were discouraged; the adoption of Western-style leather shoes was considered a sign of the success of the "civilization and enlightenment" movement. In the Meiji period, police would punish people walking barefoot, based on

49. See Ayako Hotta-Lister, The Japan-British Exhibition of 1910: Gateway to the Island Empire of the East (Richmond, Surrey: Japan Library, 1999); Yoshimi Shunya, Hakurankai no seijigaku: manazashi no kindai (Tokyo: Chūō Kōronsha, 1992), pp. 180-217. In the JapanBritish Exhibition, the Japanese government featured Ainu people, Taiwanese aborigines, and Koreans to demonstrate that Japan was improving the lives of its "uncivilized" colonized. During the first half of the twentieth century, the Japanese government continued to hold expositions in the metropole and in its colonies to display its growing power and empire. See $\mathrm{Lu}$ Shaoli, Zhanshi Taiwan: quanli, kongjian yu zhimin tongzhi de xingxiang biaoshu (Taipei: Maitian Chuban, 2005).

50. Taiwan nichinichi shinpō, November 1, 1910. The "Japanese city" was designed to show the commercial and industrial development of the country, and "Uji village" showed Japanese rural life. The commission mentioned in the text referred to the Commission of the Japan-Britain Exhibition (Nichiei Hakurankai Jimukyoku) created to take charge of the exhibition. 
the prohibition of public nudity in the Ordinances. ${ }^{51}$ In May 1901, the Tokyo Metropolitan Police Department issued a prohibition against walking barefoot in public, mainly to prevent the plague but also with the aim of eradicating this old custom especially among "coachmen, rickshaw men, stablemen, and other laborers." ${ }^{.52}$ What to wear was another concern of the Japanese elites. Barefoot Japanese were first encouraged to wear straw sandals or rubber-soled cloth footgear called jika-tabi ("socks contacting the ground"), to get them used to footwear and for ease of work. ${ }^{53}$ The traditional geta also became an embarrassment to the Japanese elites because of the reaction of Westerners who "laughed a lot about the geta thing in newspapers when they first came to Japan." Not only were geta considered dangerous and inconvenient because of their shape; the bare feet in the geta were considered offensive and inappropriate. ${ }^{54}$ The fact that the Japanese who worked in the Japan-British Exhibition still wore sandals without socks showed that this custom had not totally disappeared from Japanese society; this practice immediately became discouraged by the Japanese authorities when its people crossed borders. As the Japanese correspondent determinedly stated at the end of the article, the image of Japanese citizens in London had implications for "the credibility of every Japanese," and their scandalous behavior had "blackened the prestige of [our] country." ${ }^{55}$ While the Japanese body during the Meiji period went through a process of self-domestication, it was regulated again, by the colonial authorities, as soon as the Japanese arrived in Taiwan in 1895.

\section{Clothing the Japanese Colonizers}

Soon after their arrival in Taiwan, the Japanese faced an urgent need to reconstruct their own identity as "colonizer" who had come on a civilizing mission. During the first five years of colonization, only about 15 per cent of Japanese arrivals each year came from the three cities of Tokyo, Kyoto, and Osaka, while the remaining 85 per cent were originally from Kyushu and western and central Honshu. ${ }^{56}$ In other words, the majority of the first

51. See Kawasaki, Meiji Tōkyō shiwa, p. 45.

52. Nakayama Yasumasa, ed., Shinbun shūsei Meiji hennenshi (Tokyo: Rinsensha, 1940), p. 260. This prohibition is based on Article 426-4 of the Penal Code of Japan of 1880. It concerned offense against regulations on the prevention of infectious diseases and protection of public health.

53. See Yanagita Kunio, Meiji Taishōshi: Sesō hen, Vol. 4 (Tokyo: Asahi Shinbunsha, 1931), pp. 30-34. Jika-tabi were also called hadashi-tabi, literally “ barefoot in socks.” Matsumura Akira, ed., Daijisen (Tokyo: Shōgakkan, 1998), p. 2131.

54. Meiji Bunka Kenkyūkai, Meiji bunka zenshū: dai 21-kan, bunmei kaika hen (Tokyo: Nihon Hyōronsha, 1993), pp. 9-10.

55. Taiwan nichinichi shinpō, November 1, 1910.

56. This estimate is based on the annual official statistics published by the GovernmentGeneral from 1897. According to the Government-General, it was because of geographical 
Japanese to arrive came from the rural areas of the metropole. Most of them were also members of the lower classes who were looking for new opportunities in the new colony. They were often described as having "negative characteristics, bad manners and lifestyles, [and] appeared inferior to the Taiwanese." ${ }^{57}$ The chief of the Civil Affairs Bureau, Gotō Shinpei, even expressed regrets about the quality of the first Japanese police recruited for Taiwan. He stated that they only wanted to take advantage of the boat ticket to Taiwan paid for by the government and had left Japan with tools for carpentry and plastering so they could earn a living in case they lost their jobs. ${ }^{58}$ The looser mores of the newly arrived Japanese and their lack of concern about public nudity became a worry for the colonial authorities. During the first decade of colonization, several orders and regulations were issued to ban public nudity among the Japanese. These measures were addressed to different groups of subjects, reflecting the composition of the Japanese arrivals in different periods.

Due to restrictions on Japanese civilians coming to Taiwan for commercial purposes in the first months of colonization, soldiers, officers, civilians attached to military service (ninpu), and employees of the GovernmentGeneral of Taiwan initially represented the majority of Japanese on the island. At the very beginning of colonial rule, in June 1895, the GovernorGeneral of Taiwan, Kabayama Sukenori, published a circular focusing on behavior and dress among ninpu:

Recently, ninpu have been denounced for breaking into people's houses and for other illegal behavior. It subverts the discipline and morals of our army, damages the credibility of the empire, and degrades the prestige of the country. Hereafter, the chief of each regiment and troop will set up a regulation to correct and prohibit these abuses.

In addition, the dress of ninpu is not unified and some of them walk naked on the street. This risks causing a deterioration of discipline and morals; a general regulation should be set up in the near future to make them dress in momohiki [traditional work pants] and to strictly forbid nudity. Transgressors will be arrested by the military police and severely punished. ${ }^{59}$

proximity that Japanese from Kyushu made up the majority in Taiwan. Moreover, Japanese from the Tōhoku area had less need to move to Taiwan than those from other parts of Honshu because they were closer to Hokkaido with its abundant resources. Rinji Taiwan Kokō Chōsabu, Meiji sanjūhachinen rinji Taiwan kokō chōsa kijutsu hōbun (Taipei: Rinji Taiwan Kokō Chōsabu, 1908), p. 380.

57. Cited in Takenaka Nobuko, Shokuminchi Taiwan no Nihon josei seikatsushi (Meiji hen, Vol. 1) (Tokyo: Tabata Shoten, 1995), pp. 49-52. See also the descriptions in Washinosu Atsuya, Taiwan keisatsu yonjūnen shiwa (Tokyo: Ryokuin Shobō, 2000), p. 85.

58. Cited in Huang Zhaotang, Taiwan zongdufu, trans. Huang Yingzhe (Taipei: Qianwei Chubanshe, 2002), p. 235.

59. Taiwan Sōtokufu, comp., "Ninpu torishimari ni kansuru kokuyu," in Taiwan Sōtokufu kōbun ruisan, June 12, 1895, Vol. 11, file 26. 
This circular was written in the chaotic first months of colonization, when the Japanese army was seeking to take control of the new colony in the face of resistance by local armed forces. On May 29, 1895, the Japanese army landed in Keelung, and it took over Taipei on June 14. The Japanese army continued southward, and the fall of Tainan on October 21 represented the end of local opposition. ${ }^{60}$ The civilians attached to military service were in charge of supplies and the transport of resources. They were called ninрu or gипри (literally "laborers attached to the army"). Ninpu were directly employed by independent contractors and the army did not issue them uniforms. They were mostly uneducated and were not trained as formal soldiers. During the first Sino-Japanese War of 1894-95, Japan had mobilized about 240,000 soldiers and more than 100,000 laborers attached to the army. ${ }^{61}$ During the first months of the colonization of Taiwan, between May and September 1895, more than 73,000 Japanese arrived on the island, of whom 46,000 were soldiers and 26,000 were laborers attached to the army. ${ }^{62}$

The behavior of the ninpu in Taiwan created numerous problems for the Government-General. A circular published by the chief-of-staff of the Taiwan Garrison, Ōshima Hisanao, in October 1895 stressed the necessity of reinforcing discipline in the army:

The laborers and mechanics attached to the army are despicable types who unfortunately did not receive any education. . . If these people arrive on enemy territory or in a new colony, we risk suffering considerable consequences. Thus, it is without surprise that recently [I discovered] by reading reports that had arrived at my office that people from our country, especially laborers and mechanics attached to the army, have damaged the discipline and morals of the army, and some have even faced legal proceedings. It is dreadful that this kind of person makes our entire people extremely ashamed. ${ }^{63}$

This circular shows the changing standards for the Japanese lower classes as they moved from the home country to the colony. As soon as they arrived in the colony, they were expected to participate in the construction of the prestige of Japan and to behave like a "civilized" colonizer-the "civilized"

60. However, the last big local insurrection did not end until 1915. For the takeover of the major cities in Taiwan by the Japanese army during the early months of colonization, see Rikugun Sanbō Honbu, ed., Meiji nijūshichi-hachinen Nisshin senshi, Vol. 7 (Tokyo: Tōkyō Insatsu Kabushiki Kaisha, 1907).

61. Ōtani Tadashi, Heishi to gunpu no Nisshin sensō: senjō kara no tegami o yomu (Tokyo: Yūshisha, 2006), pp. 6-8.

62. Washinosu, Taiwan keisatsu yonjūnen shiwa, p. 193.

63. Taiwan Sōtokufu, comp., "Gunki fūki ni kansuru Ōshima (Hisanao) sanbōchō kokuyu," in Taiwan Sōtokufu kōbun ruisan, December 26, 1895, Vol. 492, file 24. Besides public nudity, there were several cases of opium and rape of local women by ninpu. 
behavior that the ruling classes had attempted to impose on them since the beginning of the Meiji regime. One of the first measures taken by the colonial authorities was to attempt to ensure that the bare body was covered.

The Government-General's disquiet about Japanese public nudity was not limited to the ninpu. A few days after Kabayama's June 1895 circular, a prohibition of nudity among employees of the Government-General was issued by the Civil Affairs Bureau. It specified that the existence of uncovered bodies among its employees "concerns the prestige of the GovernmentGeneral and its consequence is far from negligible." ${ }^{\circ 4}$ Several similar circulars concerning nudity were published during the early period of colonization in an effort to maintain discipline among the Japanese working in public service; some especially targeted those who "have direct contact with [the colonized] people." ${ }^{65}$ It is clear that the reinforcement of the selfdomestication of the body of the colonizer was stimulated by the gaze of the colonized people. Simultaneously with the promulgation of the prohibition of nudity among employees of the Government-General, the Civil Affairs Bureau published another order, prohibiting its employees from wearing Chinese-style clothes because "it not only damages morals but also risks causing the prestige [of the authorities] to deteriorate." ${ }^{66}$ This prohibition took on significance in the context of China's defeat in the Sino-Japanese War and the decadence of China in the eyes of the vanquisher. The representation of the body of Japanese people in Taiwan was thus carefully regulated by the Government-General as Japan emerged as a new colonial power in Asia.

In response to the circular of Kabayama Sukenori on the nudity of the ninpu, the first ikeizai was promulgated in colonial Taiwan in August 1895. Different from later ikeizai, it was enacted in the form of a single special law but not of a set of regulations. It was specifically targeted at every Japanese in Taiwan who went out with thighs uncovered, and fines could be imposed in cases of abuse. ${ }^{67}$ The first ikeizai published in Taiwan showed the embarrassment of the Government-General over the nudity of Japanese citizens

64. Taiwan Sōtokufu, comp., "Shisei no bunran torishimari ni kansuru ken," in Taiwan Sōtokufu kōbun ruisan, June 21, 1895, Vol. 54, file 7.

65. See Taiwan Sōtokufu, comp., "Shippō kanri no fūki hinkō seishukuhō kunrei," in Taiwan Sōtokufu kōbun ruisan, January 1, 1900, Vol. 492, file 24; Taiwan Sōtokufu, comp., "Hontō kanri fūki torishimari ue ni tsu chūyikata tsūchō," in Taiwan Sōtokufu kōbun ruisan, October 30, 1902, Vol. 721, file 5.

66. Taiwan Sōtokufu, comp., "Fūki bunran torishimari ni kansuru ken," in Taiwan Sōtokufu kōbun ruisan, June 22, 1895, Vol. 54, file 8. The circular mentioned that Japanese employees of the Government-General preferred wearing Chinese-style clothes for economic reasons and for comfort in hot weather.

67. Taiwan Sōtokufu, comp., "Ikeizai seitei," in Taiwan Sōtokufu kōbun ruisan, August 5, 1895, Vol. 11, file 39. A transgressor would be fined between 50 and 150 sen. 
in the colony. By regulating and covering the bodies of the Japanese, the colonial authorities sought to establish their credibility and esteem among the colonized people who were resisting the new regime.

The body of the Japanese colonizer in the colony was also positioned in a double gaze: the gaze of its colonized people and that of Westerners present in Taiwan. One newspaper article entitled "Don't Expose the Bare Body" published in 1898 reveals the delicate position of the Japanese body under the Western gaze, even in its own colony:

[I've already heard that] migrant workers [dekaseginin] [of our country] living abroad walked naked on the street and the Westerners passing by them shouted "how shameful!" and hid their faces in their hands. Later, the Westerners told others that the Japanese customs are much worse than the Chinese. Ten days ago, someone told me that when he was on the train from Taipei to Keelung, there was a Japanese in the second-class car who did not look vulgar but who began to take off his shirt to change to another. Two British men in the same car looked at each other, gave a bitter smile, and whispered to each other. ${ }^{68}$

While during the early Meiji period the body of Japanese "citizens" had encountered the contemptuous Western gaze, it was now the body of "colonizers" from Japan, the only Asian colonial power, which was under the gaze of Western colonial powers. Thus, the criticism from Westerners in Taiwan, who represented only a tiny part of the population on the island during the early years of colonial rule, remained significant for the Japanese as they sought to make themselves equal to the Western colonial powers. ${ }^{69}$ The journalist commented at the end that public nudity was considered shameful behavior by Westerners as well as by Japanese. Despite his effort to show that the Japanese had the same criteria of morals and decency as Westerners, the newspaper article shows Japan's embarrassing position between the "civilized" Western and "uncivilized" Asia: Japan had charged itself with a civilizing mission in Asia and at the same time strove to distinguish itself from its Asian neighbors, but by Westerners, it was inevitably compared to its defeated foe, China.

\section{Clothing First the Japanese Colonizers}

In April 1896, restrictions on the arrival of Japanese civilians in Taiwan were lifted..$^{70}$ The presence of soldiers and laborers attached to the army on

68. Taiwan nichinichi shinpō, May 15, 1898.

69. According to the statistics of the Government-General of Taiwan, only 90 Westerners lived in Taiwan in 1899. Taiwan Sōtokufu, Taiwan Sōtokufu daisan tōkeisho (Taipei: Taiwan Sōtokufu, 1901), pp. 120-21.

70. Taiwan Sōtokufu, comp., "Senryōchi shōsen shōko torishimari kisoku haishi," in Taiwan Sōtokufu kōbun ruisan, March 15, 1896, Vol. 10, file 18. 
the island progressively diminished at the same time as the number of Japanese civilian arrivals increased. ${ }^{71}$ Thereafter, the colonial authorities' concern regarding Japanese public nudity shifted toward these new arrivals who engaged in different kinds of jobs in Taiwan and were in constant contact with the Taiwanese people. The "scandalous" public nudity of Japanese in Taiwan was a frequent sight and was greatly criticized by the Japanese elites:

Japanese, both women and men, complaining about the hot weather, show their bare bodies with ease in front of everyone, wearing only fundosh $i$ and koshimaki [a Japanese petticoat or kimono underskirt]. One night, because of the heat, a Japanese couple that keeps an ice cream shop in Mengjia even slept naked on a mat on the ground in front of the shop. A policeman finally noticed them because Taiwanese were gathering around and laughing. In Taiwan, only physical laborers such as coolies are half-naked during their work; Taiwanese women, even maids and members of the lower class, are always neatly dressed with their hair well fixed. ${ }^{72}$

Japanese observers in Taiwan often emphasized that most Taiwanese laborers were bare chested, contrary to other local people who avoided baring their bodies in line with traditional mores. It was shameful in the eyes of the Japanese elites that Japanese people in the colony behaved like the lower classes of the colonized people. When the chief of the Bureau of Telecommunications of Taiwan, Kanokogi Kogorō, gave a speech at the Society of Education in Taiwan in 1902 about the improvement of customs, he pointed out that the public nudity of the Japanese should be brought to an end because of their important mission to educate the second generation of the colonized people:

Therefore, it is very important to maintain one's character and dignity, but a lot of people in our country do not seem to have this idea in mind. Especially among the lower class, people walk naked in the city or with their legs uncovered ... only people in South America or South Africa are not ashamed of being topless or naked ... and even in Korea or China this does not exist. ... Fortunately, it is comforting that this injurious custom does not exist among the Taiwanese. ${ }^{73}$

The difference in mores and bodily practices between Japanese and Taiwanese women deconstructed further the presumed "civilized" position of the colonizer. During the early Meiji period, the daily practice of bathing in Japan often shocked Westerners when they witnessed Japanese women showing their naked bodies while taking a bath in front of their houses

71. Washinosu, Taiwan keisatsu yonjūnen shiwa, pp. 194-95.

72. Quoted in Takenaka, Shokuminchi Taiwan no Nihon josei seikatsushi (Meiji hen, Vol. 1), pp. 49-50.

73. Kanokogi Kogorō, "Fūzoku kairyō ni tsukite," Taiwan kyōikukai zasshi, No. 87 (1902), p. 9. 


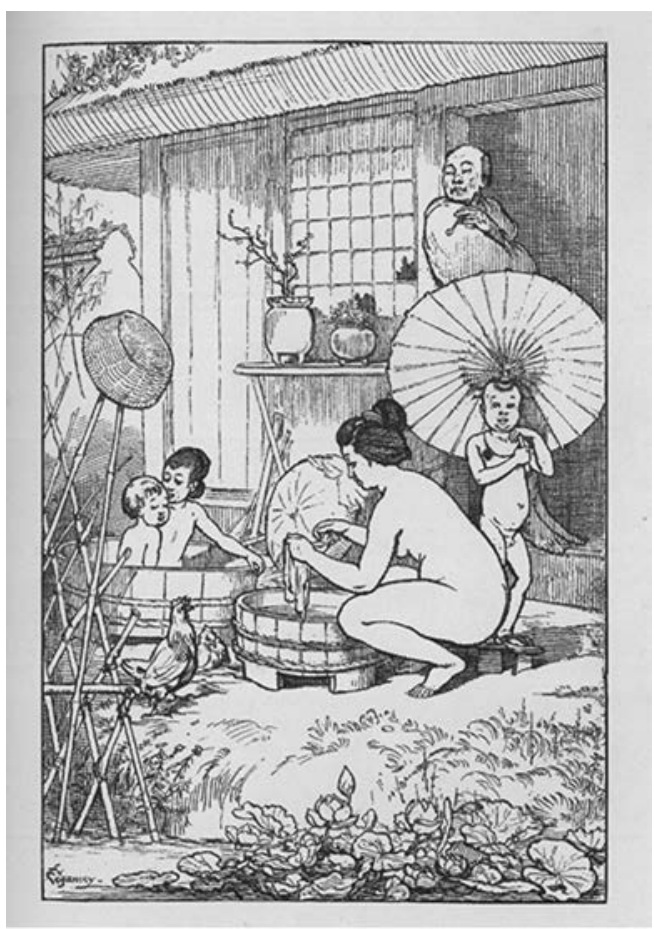

Figure 6. Emile Guimet, Promenades japonaises (Paris: G. Charpentier, 1878) (no pagination). Collection of the library of the Institute for Advanced Studies on Asia, University of Tokyo. This illustration depicts the daily scene of Japanese people bathing in front of their house in public view, as seen by the French traveler Emile Guimet.

in full view of the public (see Figure 6). Despite the Meiji government's prohibition, this habit persisted among the lower classes in Japan, and it was again forbidden by the colonial authorities when the Japanese came to Taiwan.

In 1901, Taizhong Prefecture issued an order prohibiting Japanese from taking baths in front of their houses where passersby could see their naked bodies. ${ }^{74}$ In Taiwan, the local people generally just wiped their bodies, using a washbasin in the bedroom, and they rarely took baths. The traditional mores in Chinese culture strictly forbade women from exposing their bodies, regardless of their social class. Even after public baths became common in the cities after the arrival of the Japanese, Taiwanese women were slower to use them than Taiwanese men because women were reluctant to appear

74. See Taizhong Prefecture Order No. 16 in Taichū mainichi shinbun, June 4, 1901, Appendix No. 30. 
naked in front of others. ${ }^{75}$ The difference in mores and bodily practices between Japanese and Taiwanese women often caused mockery among the Taiwanese:

It is impossible to see [the bare body of] the Taiwanese women (the upper class) because generally they always stay indoors. Even lower-class women would never expose their bodies. By contrast, among Japanese women, the nude body is frequently seen, even among noble women, when they take a bath or change their clothes, and public nudity among lower-class women is of course a common sight. When seeing this, Taiwanese people often make fun of it. Japanese in Taiwan should be fully aware of this. ${ }^{76}$

The ikeizai issued by the Government-General in 1895 on the prohibition of Japanese public nudity was ineffective, being enacted in the form of a single special law. ${ }^{77}$ New ikeizai were issued to solve the problem of Japanese public nudity in Taiwan, which worsened with the arrival of Japanese civilians. From 1896, prefectures were authorized to issue ikeizai depending on local circumstances. Ikeizai issued by the prefectures were similar to the Ordinances published in early Meiji Japan and contained a series of articles aimed at restraining behavior deemed to conflict with modern criteria regarding hygiene, public security, and decorum. They were applied to both Taiwanese and Japanese, but with some exceptions: most ikeizai included articles on the prohibition of public nudity, which were applied only to the Japanese in Taiwan. Early in 1896, the Government-General also transplanted to Taiwan the Japanese system of summary judgment that made enforcement of ikeizai more efficient. This gave police the power to administer punishments of detention and fines. ${ }^{78}$

75. The Japanese often criticized such personal cleaning practices as unsanitary and considered them proof of the uncivilized nature of the Taiwanese. According to Japanese observers, two other reasons prevented Taiwanese women from going to the public bath. First, their bound feet made taking a bath complicated. With the disappearance of the practice of foot binding during the 1910s and the promotion of sanitary and female education on the island at the same time, the younger generation of Taiwanese women seemed more inclined to use public baths. Second was the inclination of Taiwanese women to save water. Before the chief of the Civil Affairs Bureau Gotō Shinpei invested in the construction of a city water system in Taiwan, Taiwanese people used well or river water for daily use. Because access to water was not easy, people used it sparingly. Matsui Gagawa, "Hontō no josei wa naze nyūyoku o kirafu ka," Taiwan keisatsu jihō, No. 42 (1931), pp. 3-4; Okabe-sei, "Buraku yokujō no teishō," Hōmen jihō, No. 42 (1936), pp. 38-41.

76. Kataoka Iwao, Taiwan fūzokushi (Taipei: Taiwan Nichinichi Shinpōsha, 1921), p. 164.

77. Xu, "Taiwan rizhishiqi fanzui jijue zhidu chutan," p. 187.

78. For the system of summary judgment in colonial Taiwan, see Wang, Taiwan rizhishiqi de falu gaige, pp. 100-101, 218-26, 266-73; Xu, "Taiwan rizhishiqi fanzui jijue zhidu chutan," pp. 179-228. 
In August 1896, Taipei Prefecture was the first in Taiwan to publish ikeizai and issued seven articles, of which the last prohibited "dressing in disgraceful and strange dress in places where it can be seen by the public." 79 A few days later, the Ministry of Internal Affairs of Taiwan asked Taipei Prefecture to specify the intent and content of this last article, afraid that its ambiguity would cause confusion and lead to inappropriate punishment. The reply from Taipei Prefecture tells us what was considered inappropriate nudity in the eyes of the colonial authorities and indicates the context in which such a prohibition was deemed necessary. The explanation was given in four points:

- Disgraceful dress refers in general to clothes which could cause an unpleasant feeling among the public, such as men wearing sleeveless kataginu ${ }^{80}$ or wearing fundoshi and sarumata [underpants] covering only a part of their body, or women who walk in the city wearing hoso obi [a thin sash].

- Strange dress refers in general to clothes which could cause a strange feeling among the public, such as men wearing women's clothes or women wearing men's clothes.

- The spirit of this article is based on the intent to maintain the morals of society in order to make the people on the island more evolved.

- The initiative for this article came from the fact that since the lifting this April of the regulations prohibiting merchants and commercial ships [shōsen shōbai torishimari kisoku], lower-class Japanese have been arriving in Taiwan and behaving like barbarians. For example, they walk around the city during the daytime in clothes that upset the public. This causes disgust among the Taiwanese people and risks threatening the credibility of the Japanese. The purpose of this article is thus to avoid this situation by means of police control. ${ }^{81}$

79. Taiwan Sōtokufu, comp., "Taihokuken kenrei kōdaijūnigō-Taihokuken ikeizaimoku," in Taiwan Sōtokufu kōbun ruisan, August 6, 1896, Vol. 88, file 8.

80. Kataginu generally refers to a sleeveless jacket with wing-like shoulders, used by the samurai class as formal wear during the Edo period. Originating as early as the eighth century, this dress also influenced the daily wear of the lower-class Japanese and was called generally menokataginu. The menokataginu is a sleeveless top that covers only the shoulders and the back. It was made with low-quality fabrics such as hemp and cotton that farmers had been limited to using from the early Edo period. During the summertime, lower-class people would simply wear a menokataginu that barely covered the rest of the body. Without specification of kataginu in the explanation given by Taipei Prefecture, the context suggests that it probably referred to menokataginu. See Takahashi Kenji, Nihon fukushoku shiron (Tokyo: Daitōkaku, 1927), pp. 176-200; Matsuo Ryoko, "Momen orimono no juyō katei to yanaijima ni kansuru ichi kōsatsu," Yamaguchi Kenri Daigaku seikatsu kagakubu kenkyū hōkoku, Vol. 31 (2005), pp. 21-23.

81. Taiwan Sōtokufu, comp., "Taihokuken kenrei kōdaijūnigō-Taihokuken ikeizaimoku," in Taiwan Sōtokufu kōbun ruisan, August 6, 1896, Vol. 88, file 8. 
The lifting of the prohibition of merchants and commercial ships mentioned in the text referred to the beginning of the arrival of Japanese civilians in 1896. As a consequence, and as the above explanation underlines, the looser mores of the lower classes of Japanese coming in great numbers to the colony were regarded as disturbing the credibility of the colonial authorities. The traditional Japanese clothing mentioned in the first point of the explanation by Taipei Prefecture reminds us of the illustrated Ordinances published in Japan during the early Meiji period, in which we can frequently find representations of seminaked men wearing nothing but a fundoshi or sarumata (see Figures 4 and 5). These old habits forbidden to the "modern" and "civilized" Japanese citizen still remained in Japanese society and became a problem for the Government-General when Japanese citizens crossed over to the colony. Thus, the seminaked body of the Japanese had first to be clothed in order to place the colonizer back in its superior "civilized" position.

Even if the last article in the ikeizai of Taipei did not specify the Japanese in particular, contrary to ikeizai issued later by other prefectures, Taipei Prefecture's explanation to the Ministry of Internal Affairs showed clearly that it was aimed mainly at the Japanese on the island. The official newspaper Taiwan nichinichi shinpō, from its establishment in May 1898, frequently reported cases of punishment of Japanese in Taipei because the police found them scantily dressed in public. Taipei ikeizai allowed police to impose detention limited to three days or a fine of 20 to 125 sen in the case of a contravention of the prohibition against public nudity. Because police in colonial Taiwan were empowered to administer the punishment on their own accord, the penalty imposed was often rather subjective. From the cases reported in the Taiwan nichinichi shinpō, it appears that many times the police strictly admonished (setsuyu) the offenders instead of imposing a detention or fine; but in other cases the police imposed both a fine and detention.

There were also reports of Taiwanese being stopped by the police because of public nudity, even if this prohibition was applied specifically to Japanese. There do not seem to have been any essential differences between the punishments imposed on Taiwanese and Japanese offenders where public nudity was concerned ${ }^{82}$ However, there was a difference in the proportion of Japanese and Taiwanese offenders in Taipei. A newspaper article in 1902

82. In 1904, in order to reduce the number of individuals in custody, the GovernmentGeneral restored caning, which had been part of the traditional Chinese legal system, even though in Japan caning had been abolished under the Penal Code of 1882. Caning in colonial Taiwan was applied exclusively to Taiwanese and Chinese workers and not to Japanese and could replace detention and fines in the case of minor contraventions. However, there are no records proving that Taiwanese were caned in cases of public nudity. For caning as applied in colonial Taiwan, see Wang, Taiwan rizhishiqi de falu gaige, pp. 268-69; Gotō 
states: "Recently, cases of public nudity have increased and the number of offenders is up to more than 20 persons per day. Among them, the majority are Japanese, while Taiwanese are relatively rare. ${ }^{, 83}$ Besides the different mores and perceptions about nudity of the Japanese and Taiwanese, the fact that the colonial authorities paid particular attention to regulating the bare body of the Japanese meant the colonizers were the major offenders of public nudity regulations in Taiwan.

The prohibition against wearing a hoso obi, as mentioned in Taipei Prefecture's explanatory text, appeared in most of the ikeizai published in Taiwan. When present, it was included under the article concerning the prohibition of public nudity, with Japanese women as its exclusive subject. The hoso obi was a belt used by Japanese women on less formal occasions with an everyday kimono, while a broad $o b i$ was used for more formal occasions. Wearing a kimono tied with a thin sash easily exposed a woman's upper body, and this mode of dress was described as "dressing in a thin sash" (hoso obi sugata) and "nudity in a thin sash" (obishiro hadaka), metamorphosing it to an articulation of nudity ${ }^{84}$ In the late Edo period, the way in which women tied the sash revealed their social class, and lower-class women often dressed with a thin sash for ease of work: "The landladies in nagaya [a Japanese row house] somehow rarely wore their kimono properly or tied the sash neatly. Lots of them usually wore koshimaki and juban [under kimono] tied with a thin sash and even went out like this in an unconcerned manner." ${ }^{\circ 5}$

From the Meiji era, dressing using a hoso obi came to be regarded as contravening modern criteria for public morals and decency. In June 1875, a newspaper reported the case of a geisha in Tokyo who "dressed in a thin sash" in the heat and relaxed on the passageway along the edge of the house. A policeman passing by saw her and charged her with violating the Ordinances concerning public nudity (Figure 7) ${ }^{86}$ In 1885, on the occasion of

Takehide, "Nihon tōchi jiki Taiwan niokeru chikei nitsuite," Hōgaku ronsō, Vol. 31, No. 2 (2014), pp. 37-51.

83. Taiwan nichinichi shinpō, July 30, 1902.

84. See the definition of hoso obi sugata in Heibonsha, ed., Daijiten, Vol. 23 (Tokyo: Heibonsha, 1953), p. 222, and obishiro hadaka in Heibonsha, ed., Daijiten, Vol. 5 (Tokyo: Heibonsha, 1953), p. 160; Shinmura Izuru, ed., Köjien (Tokyo: Iwanami Shoten, 1998), p. 39. There also exist the expressions obihiro hadaka and obihiro doke describing women wearing kimono without using a sash and exposing their half-naked bodies. See Heibonsha, ed., Daijiten, Vol. 5, p. 163; Shinmura, ed., Kōjien, p. 395; Maeda Isamu, ed., Edogo daijiten (Tokyo: Kōdansha, 1974), pp. 208-9.

85. Kawasaki, Meiji Tōkyō shiwa, pp. 38-39. See also the evolution of the use of the sash during the Edo period in Kanazawa, Edo fukushokushi. During the Edo period, the stores of wealthy merchants were in independent buildings facing main streets, while small merchants and craftsmen rented dwellings in nagaya along back streets.

86. Yūbin hōchi shinbun, No. 702, June 22, 1875. 


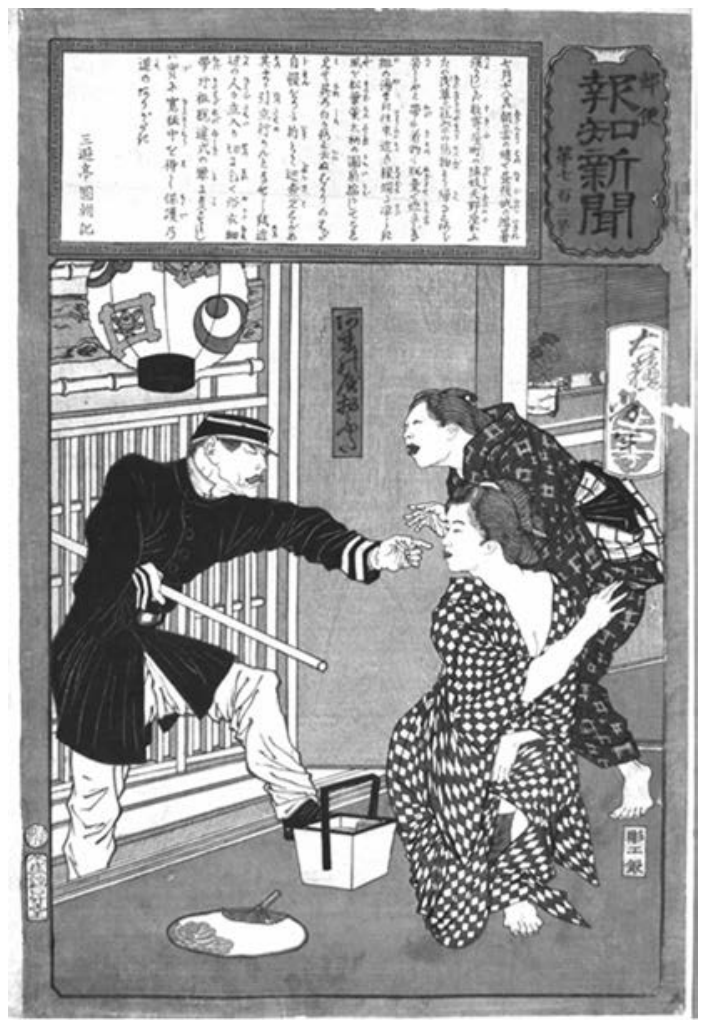

Figure 7. Yūbin hōchi shinbun, No. 702, June 22, 1875. Waseda University Japanese and Chinese Classics Collection (reproduced by kind permission of Waseda University Library).

the International Hygiene Exhibition in Berlin, a Japanese correspondent of the Tókyo nichinichi shinbun complained that among the Japanese craftsmen participating in the exhibition, "men wore yukata with a sash three feet long and women wore yukata with a thin sash," and they "all walked either barefoot or with creaking geta." This "shameful" and "vulgar" look, as described by the journalist, brought mockery by Westerners. He thus suggested that Japanese dress should be improved so that the country would be able to be "situated in the same position as civilized countries." ${ }^{\text {" }}$ But before the use of the hoso obi disappeared totally from the country under Meiji government control, it became a concern for the colonial authorities following the arrival of Japanese civilians in the colony.

87. Tōkyō nichinichi shinbun, August 7, 1885. The "three-foot sash" (sanjaku obi) was commonly adopted by workmen during the Edo period. Ôtsuki Fumihiko, Daigenkai (Tokyo: Fuzan̄bō, 2001), p. 880; Maeda, ed., Edogo daijiten, p. 451. 
In colonial Taiwan, the prohibition against the hoso obi also reflected the movement of numerous Japanese geisha and prostitutes from the mainland to the colony. They were the first Japanese women to arrive in Taiwan after the opening of the borders to Japanese civilians. Though the unstable situation and bad living conditions on the island during the first years of colonization discouraged the arrival of ordinary Japanese women, great numbers of prostitutes and geisha arrived in response to the large presence of male officers and soldiers. One month after the relaxation of restrictions in 1896, more than 800 prostitutes and geisha had arrived in Taiwan; in June, the total number had already risen to more than 2,000, not counting those whose arrival was not officially recorded because of the incomplete administrative system during the early years of colonization. ${ }^{88}$ Presumably around half of the 7,824 Japanese women arriving in Taiwan in 1897 were engaged in sex-related business, and they were frequently marked by their hoso obi, as described in one newspaper: "[these Japanese prostitutes] are inappropriately dressed in hoso obi and walk seminaked in the street with tousled hair, as if they have just woken up." ${ }^{89}$ The colonial authorities quickly forbade this mode of dressing.

Hōko Prefecture (the Pescadores Islands, situated in southwest Taiwan) prohibited the hoso obi as early as July $1896 .{ }^{90}$ The prohibition was addressed exclusively to Japanese women, probably because of the large presence of Japanese prostitutes and geisha on these islets where the Japanese military was stationed. According to the official statistics of 1899 , more than half of the 243 Japanese women living in this prefecture worked in sexrelated businesses. ${ }^{91}$ This prohibition was published in the form of a single special law and it forbade the wearing in public of a kimono "in the abnormal way with a hoso obi," as well as other types of scandalous behavior displaying the nude body. ${ }^{92}$ The restriction on the hoso obi later appeared in

88. Tōhoku shinbun, June 3, 1896; Taiwan nipō, June 17, 1896; Taiwan nichinichi shinpō, June 17, 1896.

89. Taiwan nichinichi shinpō, June 17, 1896. In 1897, the ratio of Japanese men and women living on the island was about three to one. Taiwan Sōtokufu, Taiwan Sōtokufu daiichi tōkeisho (Taipei: Taiwan Sōtokufu, 1899), pp. 50-52. The total number of Japanese prostitutes and geisha in Taiwan in 1897 is unknown because many of them worked without the permission of the colonial authorities and under the disguise of various businesses in the service industry, such as restaurant and hotels. According to a police report of November 1897, there were over 400 Japanese business operations related to the sex industry (exact number of working women unknown) and 437 geisha, all of which worked illegally in Taipei Prefecture. Taiwan nichinichi shinpō, December 9, 1897.

90. Taiwan Sōtokufu, comp., "Hōkodōchōrei kōdainigō naichifujin fukusō torishimari tsuki naikun daiichigō," in Taiwan Sōtokufu kōbun ruisan, July 9, 1896, Vol. 86, file 35.

91. Taiwan Sōtokufu, Taiwan Sōtokufu daisan tōkeisho, pp. 204-5.

92. Taiwan Sōtokufu, comp., "Hōkodōchōrei kōdainigō naichifujin fukusō torishimari tsuki naikun daiichigō," in Taiwan Sōtokufu kōbun ruisan, July 9, 1896, Vol. 86, file 35. Four 
ikeizai enacted by other prefectures in Taiwan as more and more Japanese lower-class women apart from prostitutes and geisha arrived on the island. The prohibition of the hoso obi was a consequence of the specific economic context at the end of the nineteenth century and a trace of the move of Japanese women across borders.

Through regulations aimed exclusively at Japanese public nudity in the colony, a distinction was made between the colonizer and the colonized people whose bodies were not domesticated at the same time or on the same scale. This different treatment of colonizer and colonized was later acknowledged, and a reflection on this subject appeared in Tainan in 1906:

Ikeizai of Tainan [Prefecture (chō)]—for example, the articles concerning nudity - are set up exclusively for Japanese. Although it happens that the police harshly admonish the Taiwanese people because of public nudity, the articles concerning public nudity do not specify Taiwanese as the subjects of control. Yet, there should be no political distinction between Japanese and Taiwanese and especially nudity should be strictly forbidden for moral reasons. It is thus unfair that this article is applied exclusively to Japanese. It seems that the authorities are discussing modifying the article so that nudity among Taiwanese as well as Japanese in Tainan, regardless of the subprefectures [zhiting/shichō], will be strictly forbidden. ${ }^{93}$

This newspaper article appeared in Hanwen Taiwan riri xinbao, the Chinese version of Taiwan nichinichi shinpo, which had been created to promulgate the colonial authorities' policy to the Taiwanese people, as well as to be a forum in which the local elites could express their voice. ${ }^{94}$ It showed an awareness on the part of the local elites of the existence of "inequality" between the colonizer and the colonized in terms of a discriminatory legal control on the body. While the colonial authorities focused primarily on the domestication of the Japanese nude body in Taiwan, the local elites who had been observing the self-domestication of the body of the colonizer now in turn sought to have the Taiwanese people's bodies "legally" regulated. The rising consciousness of the local elites in relation to the domestication of the Taiwanese bare body needs to be put into the context of their constant cooperation with the colonial authorities in promoting reforms of customs, such as the practices of foot binding and the hair queue, which the

months later, Hōko Prefecture issued its first ikeizai, of which the first article forbade nudity in public by Japanese, both men and women. Hōkochō, ed., "Hōkodōchōrei kōdaishichigō," in Hōkochōpō (1896).

93. Hanwen Taiwan riri xinbao, March 15, 1906.

94. Taiwan nichinichi shinpo , founded in 1898 , initially contained six pages daily, including two pages in Chinese. During the years 1905 to 1911, the Chinese version was an independent newspaper, Hanwen Taiwan riri xinbao. Japanese sinologists and Taiwanese elites and literati worked as journalists for Hanwen Taiwan riri xinbao or contributed their work to the newspaper. 
Government-General considered inheritances from "backward" Chinese. ${ }^{95}$ The reform of traditional customs in colonial Taiwan was generally initiated and promoted in a top-down fashion, with the Government-General's support. From the very beginning of colonization, the Government-General made continuous efforts to win the support of the local elites as it imposed its rule on society, while the local elites thought to reinforce their social status under the new regime and to stimulate the modernization of colonial society ${ }^{96}$ In this sense, covering the bare body of the Taiwanese people appeared to be a continuation of the local elites' efforts to modernize colonial society and gain equal status with the colonizer.

The above newspaper article was published one week after the last revision of the Tainan ikeizai on March 9, 1906. In this last revision adapted to the latest evolution of the subprefectures of Tainan, it is specified, as in the previous versions, that Articles 19 and 20 concerning the prohibition of public nudity apply exclusively to Japanese. ${ }^{97}$ This newspaper article thus appeared as a reaction to this revision, in which the prohibition of

95. The movement against foot binding was initiated in Taiwan at the beginning of the 1900s, producing effective results from the mid-1910s. The queue-cutting campaign was launched about the same time, and under similar leadership, but it was more effective because in traditional society bound feet had crucial implications for a girl's future marriage. For cooperation between the local elites and the Government-General in reforming customs, see the major contribution of Wu Wenxing, Rizhi shiqi Taiwan de shehui lingdao jieceng (Taipei: Wunan Tushu Chuban Gufen Youxian Gongsi, 2008), pp. 209-56. Other important works on the movement against foot binding in Taiwan include Kō Ikujo, Kindai Taiwan joseishi: Nihon no shokumin tōchi to "shinjosei" no tanjō (Tokyo: Keisō Shobō, 2001), pp. 23-72; Chen Chu-Fang, "Kaitensoku undō (1900-1915) no ichikōsatsu-Nihon shokumin tōchi ka no Taiwan ni oite," Chiki bunka kenkyū, No. 2 (1991), pp. 5-31.

96. Previous contributions to our understanding of the cooperation between the colonized people and the Japanese colonial authorities have highlighted "collaboration with Japan" (tainichi kyōryoku) and underlined its importance to the modernization of colonial society. See Namiki Masahito (trans. Chen Wensong), "Chaoxian de 'zhimindi jindaixing,' 'zhimindi gonggongxing' he duirixieli-zhimindi zhengzhishi, shehuishi yanjiu zhi qianzhixing kaocha," in Wakabayashi Masahiro and Wu Micha, eds., Kuajie de taiwanshi yanjiu: yu dongyashi de jiaocuo (Taipei: Bozhongzhe Wenhua Youxiangongsi, 2004), pp. 100-110. According to the Government-General, the "local elites" of Taiwan included Taiwanese who assumed functions in the local administrative system as well as schoolteachers and intellectuals. One significant step taken by the Government-General to court the local elites was to select influential Taiwanese to undertake basic functions in the local administrative system so as to construct a new local leadership in colonial society. See Wu, Rizhi shiqi Taiwan de shehui lingdao jieceng, pp. 43-71.

97. The ikeizai of Tainan had been previously revised on May 12, 1902. Between 1902 and 1906, there were some changes in the subprefectures of Tainan. Article 19 of the ikeizai of Tainan prohibited "being naked or topless or dressing in strange dress in places where this can be seen by the public, as well as other scandalous behavior showing the nude body"; Article 20 prohibited women "from going out in hoso obi." 
public nudity still applied exclusively to the Japanese body. In 1908, the Government-General published ikeizai for Taiwan (Taiwan ikeizai) addressed to both Japanese and Taiwanese with no exceptions. ${ }^{98}$ As soon as these were enacted, ikeizai previously published by each prefecture became void. Article 2-26 of the new ikeizai of Taiwan briefly prescribed the prohibition of "expos[ing] the nude body in public." The nude body of the colonized people and the colonizer was finally examined and domesticated under the same legal criteria.

After the enactment of the 1908 ikeizai, the domestication of the bare body of both Japanese and Taiwanese continued. But compared to public nudity, which only affected the lower classes of Taiwanese men, the Government-General put more effort in the 1900s into supporting the local campaign for the abolition of the practices of foot binding and the hair queue. After these campaigns achieved distinctive results, from the late 1910s, when the assimilation movement was increasingly important in colonial policy, the Taiwanese habit of walking barefoot was taken up by the local elites and the colonial authorities. Just as the bare feet of the Japanese had been problematized by the Japanese elites during the early Meiji period, the bare feet of the Taiwanese now became part of the rhetoric of civilization. However, the Japanese seemed to forget their past, stating that the shocking sight of people walking barefoot had never been seen in Japan and concluding that the Taiwanese people were still only halfway to civilization..$^{99}$ The suppressed memory of Japan's self-domestication of the bare foot in the Meiji period transformed here into "colonial unconsciousness": the Japanese criticized the barefooted colonized by adopting the Western colonial gaze in order to justify themselves as the "civilized" ones and to render the Taiwanese into the colonial Other that must be assimilated. The Japanese in the colony of Taiwan, on the one hand, domesticated their own bodies under the gaze of the colonized people and, on the other hand, regulated the body of the colonized people by projecting onto it the gaze they had themselves suffered from Westerners from the early Meiji period. The domestication of the Japanese body as well as the Taiwanese body reveals the constant and reciprocal construction of the identity of the colonizer and colonized in relation to each other, within the convergence of tensions, ambiguities, and representations.

98. These new regulations were part of the Penal Code that came into effect in Japan and simultaneously in Taiwan the same year.

99. For moves to abolish walking barefoot in colonial Taiwan, see Ju-Ling Lee, "'Civilising' and 'Modernising' the Feet: Their Emancipation, Domestication and Aestheticisation in Colonial Taiwan (1895-1945)," European Journal of East Asian Studies, Vol. 14 (2015), pp. 225-60. 


\section{Conclusion}

The self-domestication of the Japanese nude body mirrored the particular position of Japan in the international order of the late nineteenth and early twentieth century and showed how Japanese identity was shaped and reshaped in a complex way. During the Meiji period, the Japanese ruling class, who adopted Western ideas of civilization, imposed their mores on the general public, among whom the majority was from the former lower classes. Ordinances were issued to domesticate the bare body of the latter and to form the "civilized" citizen of the modern nation. However, the hasty imposition of modernization and its uneven spread in urban and rural areas resulted in a second self-domestication of the Japanese body when numerous members of the lower classes sought opportunities in the new colony of Taiwan. As soon as the Japanese arrived there, because of the difference in mores and bodily practices between the Japanese and the Taiwanese, the colonizers had to examine and domesticate their own bodies under the gaze of the colonized people as well as the gaze of Westerners on the island. During the first decade of colonization, successive prohibitions against public nudity were targeted exclusively at the Japanese in the colony. They were at first aimed at the Japanese ninpu and employees of the GovernmentGeneral and enacted in the form of a single special law; later, after the opening of the colony to Japanese civilians in 1896, the prohibitions against public nudity were enforced by ikeizai targeted exclusively at Japanese, while the other ikeizai articles were addressed to both Japanese and Taiwanese. By first clothing the Japanese in the colony, the "civilized" status of the colonizers was established and their "civilizing" mission was justified. These regulations were an effect of the move of a certain social class and gender from the metropole to the colony as well as the fluidity of the borders between the civilized and the uncivilized. The Japanese colonization in Taiwan helped shape Japan's own bodily construction and strengthen its concept of civilization and at the same time improved the consequences of its rapid modernization during the early Meiji period. Within the economic, social, and cultural exchanges between border-crossing Japanese and the colonized people, the interactions in the colonial encounter were marked by the self-domestication of the body through which the colonizer as well as the colonized constructed their own identities in relation to each other.

UNIVERSITE DE GENEVE 